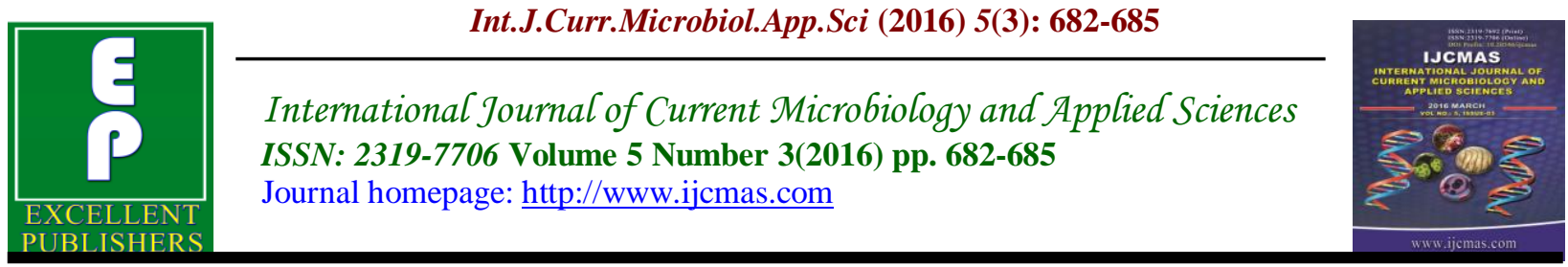

Original Research Article

http://dx.doi.org/10.20546/ijcmas.2016.503.080

\title{
Exploring Antimicrobial Activity of Sargassam wightii Extracts against Microbial Pathogens
}

\author{
G. Ashtalakshmi ${ }^{1}$ and P. Prabakaran ${ }^{2}$ \\ ${ }^{1}$ Department of Microbiology, Marudhupandiyar arts and science College, Vallam, \\ Thanjavur, Tamilnadu, India \\ ${ }^{2}$ Marudhupandiyar arts and science college, Vallam, Thanjavur, India \\ *Corresponding author
}

\begin{abstract}
A B S T R A C T
Keywords

Sargassam,

Sea weed,

Antibacterial

activity,

Antifungal activity

Article Info

Accepted:

20 February 2016

Available Online:

10 March 2016

Seaweeds are considered as a source of bioactive compounds as they are able to produce a great variety of secondary metabolites characterized by a broad wightiiectrum of biological activities. Compounds with antioxidant, antiviral, antifungal and antimicrobial activities have been detected in brown, red and green algae. Algae are the source of amino acids, terpenoids, phlorotannins, steroids, phenolic compounds, halogenated ketones and alkanes and cyclic polysulphides.In this study, antimicrobial activity of sea weed, Sargassam wightii was checked against the diabetic survival bacteria. There are three algal extracts evaluated for antibacterial activity was studied by well diffusion assay and the antifungal activity was studied by poison
\end{abstract}

\section{Introduction}

Seaweeds belong to a group of plants known as algae. Seaweeds are classified as Rhodophyta (red algae), Phaeophyta (brown algae) and Chlorophyta (green algae) depending on their nutrient and chemical composition ${ }^{1}{ }^{2}$. Like other plants, seaweeds contain various inorganic and organic substances which can benefit human health $^{3,4}$. The inhibitory substances biosynthesized by the seaweeds were noted as early as in $1917^{5,6,7}$. The first observation regarding antibiotic activities of seaweeds was reported by Pratt et al., 1944.
Recent findings evidenced that seaweeds contained antibacterial, antiviral, antifungal, cytotoxic and larvicidal potentials. ${ }^{8,9,10 .}$

\section{Materials and Methods}

The samples of Sargassam wightii were collected from the Kanyakumari coastal region during low tides. Then the seaweeds were washed thoroughly with seawater to remove extraneous materials and brought to the laboratory in plastic bags containing water to prevent evaporation. Then the 
samples were washed with distlled water twice to remove salts. Samples were then shadow dried until constant weight obtained and ground in pulverization to get coarse powder. The powdered samples subsequently stored in refrigerator.

\section{Preparation of the Extracts}

Extraction of algal material was prepared according to the methodology of Indian Pharmacopoeia. The fresh materials were dried in shade conditions and the dried materials were subjected to pulverization to get coarse powder. About 100 gm of dry sample powder was weighed and macerated with $1000 \mathrm{ml}$ of each solvent (Acetone, Aqueous and Ethanol) in a Soxhlet extractor for 6 hours. The extraction was repeated twice. The total extracts were filtered and the obtained filtrates (crude extracts) were concentrated under rotary evaporator. The extracts were stored in a refrigerator in air tight containers.

\section{Collection of Microorganisms}

Test organisms used were MTCC cultures. The pathogenic bacteria were cultured on Nutrient broth at $37^{\circ} \mathrm{C}$ for 18 hours before inoculation for assay. The bacterial stock cultures were maintained at $4^{\circ} \mathrm{C}$

\section{Antibacterial Assay}

The antibacterial activity of Aqueous, Acetone and ethanol extracts of sargassam wightii were performed by using well diffusion method.

About $20 \mathrm{ml}$ of sterile molten Mueller Hinton agar (Hi Media Laboratories Pvt. Limited, Mumbai, India) was poured into the sterile petriplates. Plates were swabbed with the overnight broth culture (108 cells/ml).
The solid medium was gently punctured with the help of cork borer to make a well. Finally the crude extracts at different concentrations $\quad(500 \mathrm{ppm}, 750 \mathrm{ppm}$ and $1000 \mathrm{ppm}$ ) were added into each well and incubated for $24 \mathrm{~h}$ at $37 \pm 2{ }^{\circ} \mathrm{C}$. After $24 \mathrm{~h}$ of incubation, the zone of inhibition was measured and expressed as millimeter in diameter.

\section{Antifungal Assay}

The culture of 48 hours old grown on potato dextrose agar was used as a inoculum in this study .

$1000 \mathrm{ppm}$ of algal extract (aqueous, acetone and ethanol) was taken, mixed with presterilized, cooled potato dextrose agar and poured in the sterilized Petri plate.

After solidification, the fungal inoculum was taken and inoculated at the center of the solidified plate. A control plate is maintained without mixing of the algal extract in the Potato dextrose agar.

Incubation period of 10 days was maintained for observation of antifungal activity of the crude plant extracts.

The complete fungal analysis was carried out in aseptic conditions.

\section{Results and Discussion}

The antibacterial activity of the crude extracts (aqueous, acetone and ethanol) was evaluated by disc diffusion assay and are listed in the table no : 01 .

The antifungal activity of the crude extracts (aqueous, acetone and ethanol) was evaluated by Poison food technique and are listed in table no : 02 . 
Table.1

\begin{tabular}{|c|l|l|l|l|l|l|}
\hline \multirow{2}{*}{ Dilutions } & \multirow{5}{*}{ Extracts } & \multicolumn{5}{|c|}{ Microorganisms } \\
\cline { 3 - 7 } & Aqueous & No acti & P. aeruginosa & K. pneumoniae & S. aureus & P.vulgaris \\
\hline $500 \mathrm{ppm}$ & Acetone & $10 \mathrm{~mm}$ & $10 \mathrm{~mm}$ & $8 \mathrm{~mm}$ & No activity & No activity \\
\hline & Ethanol & $10 \mathrm{~mm}$ & $10 \mathrm{~mm}$ & $9 \mathrm{~mm}$ & $10 \mathrm{~mm}$ & $10 \mathrm{~mm}$ \\
\hline & Aqueous & $8 \mathrm{~mm}$ & $10 \mathrm{~mm}$ & $6 \mathrm{~mm}$ & $10 \mathrm{~mm}$ & $8 \mathrm{~mm}$ \\
\hline $750 \mathrm{ppm}$ & Acetone & $12 \mathrm{~mm}$ & $14 \mathrm{~mm}$ & $10 \mathrm{~mm}$ & $12 \mathrm{~mm}$ & $8 \mathrm{~mm}$ \\
\hline & Ethanol & $11 \mathrm{~mm}$ & $12 \mathrm{~mm}$ & $11 \mathrm{~mm}$ & $12 \mathrm{~mm}$ & $11 \mathrm{~mm}$ \\
\hline $1000 \mathrm{ppm}$ & Aqueous & $10 \mathrm{~mm}$ & $10 \mathrm{~mm}$ & $9 \mathrm{~mm}$ & $10 \mathrm{~mm}$ & $10 \mathrm{~mm}$ \\
\hline & Acetone & $14 \mathrm{~mm}$ & $14 \mathrm{~mm}$ & $12 \mathrm{~mm}$ & $14 \mathrm{~mm}$ & $13 \mathrm{~mm}$ \\
\hline & Ethanol & $14 \mathrm{~mm}$ & $15 \mathrm{~mm}$ & $12 \mathrm{~mm}$ & $13 \mathrm{~mm}$ & $12 \mathrm{~mm}$ \\
\hline
\end{tabular}

Table.2

\begin{tabular}{|l|c|l|l|}
\hline & \multicolumn{2}{|l|}{ Percentage of inhibition } \\
\hline Fungi and Dilusions & \multicolumn{2}{l|}{} \\
\hline Fusarium sp & Ethanol extract & Acetone extract & Aquous extract \\
\hline $1000 \mathrm{ppm}$ & $85 \%$ & $60 \%$ & No activity \\
\hline $750 \mathrm{ppm}$ & $70 \%$ & $40 \%$ & No activity \\
\hline Candida albicans & & & \\
\hline $1000 \mathrm{ppm}$ & $80 \%$ & $70 \%$ & $20 \%$ \\
\hline $750 \mathrm{ppm}$ & $70 \%$ & $60 \%$ & No activity \\
\hline Penicillium sp & & & No activity \\
\hline $1000 \mathrm{ppm}$ & $70 \%$ & $60 \%$ & No activity \\
\hline $750 \mathrm{ppm}$ & $50 \%$ & $50 \%$ & \\
\hline
\end{tabular}

The percentage of Inhibition is Calculated as Follows

$$
\begin{aligned}
& \mathrm{MI}(\%)=\frac{\mathrm{MG}_{\text {control }}-\mathrm{MG}_{\text {treatment }}}{\mathrm{MG}_{\text {control }}} \times 100 \\
& \text { where } \mathrm{MI}=\text { mycelial inhibition } \\
& \mathrm{MG}_{\text {control }}=\text { mycelial growth of control and } \\
& \mathrm{MG}_{\text {treatment }}=\text { mycelial growth of treated sample. }
\end{aligned}
$$

The present study was carried out to analyze the antimicrobial activity of the seaweed Sargassam wightii. From this study, we can conclude that the ethanolic extract of Sargassam wightii has a very good antimicrobial activity.

\section{References}

1. Bauer, A.W., Kirby, W. M. M., Truck, H. and Shrecies, J. C. 1996. Antibiotic susceptibility testing by standardized single disc method. Am. J. Clin. Pathol., 45: 493-496. 
2. Eleanor and John Lewallen, 2009. Marine pharmaceutical guidelines. Mendocino Sea Vegetable Company P.O. Box 1265 Mendocino, CA 95460 (707): 937-2050.

3. Freile-Pelegrin, Y. and Morales, J. L. 2004. Antibacterial activity in marine algae from the coast of Yucatan, Mexico. Bot. Mar., 47: 140-146.

4. Kandhasamy, M. and Arunachalam, K. D. 2008. Evaluation of in vitro antibacterial property of seaweeds of southest coast of India. Afr. J. Biotechnol., 7: 1958-1961.

5. Kellam, S. J., Cannell, R. J. P. Owisanka, A. M. and Walker, J. M. 1988. Results of a large-scale screening programme to detect antifungal activity from marine and freshwater micro algae in laboratory culture. Br. Phycol. J. 23:45-47.

6. Kokatae. C. R., 1994. Practical pharmacognosy, Vallabh prakashan, New Delhi, India.

7. Mtolera Mwightii, Semesi AK. 1996. Antimicrobial activity of extraxts from six green algae from Tanzania. In: Current Trends in Marine Botanical Research in East African Region (ed. Björk M, Semesi AK, Pedersén M and Bergman B), SIDA, pp. 211-217.

8. Serkedjieva, J., 2004. Antiviral activity of the red marine algae Ceramium rubrum, Phytotherapy Research, 18 : 480-483.

9. Smith, A. J., 2004. Medicinal and pharmaceutical uses of seaweed natural products: a review, J. of Appl. Phycol., $16: 245-262$.

10. Tuney, I., Cadirci, B. H., Unal, D. and Sukatar, A. 2006. Antimicrobial activities of the extracts of marine algae from the coast of Urla (Izmir, Turkey). Turkish J. of Biol., 30 : 171-175.

11. Tang, H. F., Yi, Y. H., Yao, X. S., Xu, Q. Z., Zhang, S. Y., and Lin, H. W. 2002. Bioactive steroids from the brown algae Sargassum carpophyllum, Journal of Asian Natural Product Research, 4 : 95-105.

\section{How to cite this article:}

Ashtalakshmi, G., and Prabakaran, P. 2016. Exploring Antimicrobial Activity of Sargassam wightii Extracts against Microbial Pathogens. Int.J.Curr.Microbiol.App.Sci. 5(3): 682-685. doi: http://dx.doi.org/10.20546/ijcmas.2016.503.080 